\title{
高分子水溶液の多段屈曲流路流れにおける流体混合の可視化観察*
}

\author{
玉 野 真 司*1, 伊 藤 基 之*1 \\ 笹川哲*2, 横 田和彦*1
}

\section{Flow Visualization of Fluid Mixing in Curvilinear Pipe Flow of Polymer Solution}

\author{
Shinji TAMANO*3, Motoyuki ITOH, \\ Akira SASAKAWA and Kazuhiko YOKOTA \\ ${ }^{* 3}$ Graduate School of Engineering, Nagoya Institute of Technology, \\ Gokiso-cho, Showa-ku, Nagoya-shi, Aichi, 466-8555 Japan
}

\begin{abstract}
The fluid mixing in a curvilinear pipe flow of polymer solutions was investigated using the flow visualization. The number of curves $N$ was set at $1,6,32$ and 60 . As a viscoelastic fluid, polyacrylamide (PAA) solutions of 0.05 and $0.1 \mathrm{wt} \%$ were used. It was found that the drastic change of the secondary flow pattern strongly promoted the fluid mixing at $N=60$ for PAA solutions. The Reynolds number, at which the fluid mixing was promoted, became smaller with the increase in concetration of polymer solution.
\end{abstract}

Key Words : Non-Newtonian Fluid, Viscoelastic Fluid, Pipe Flow, Secondary Flow, Mixing, Flow Visualization, Curvilinear Pipe

\section{1. 緒言}

本研究で扱う曲がり管路内の流れは，基本的な流 れの一つであり，その二次流れに関してはこれまでに 数多くの数值的・実験的研究が報告されている ${ }^{(1)}{ }^{(2)}$. しかしながら，その報告例のほとんどがニュートン流 体に関するものであり，非ニュートン流体に関する研 究, 特に実験的研究 ${ }^{(3)}{ }^{(4)}$ は極めて少ない. Jones \& Davies $^{(3)}$ は曲率半径と曲がり段数が異なる円形断面心゙ ンドパイプにおける希薄高分子水溶液の圧力損失測定 を行っている，また，横山・富田 ${ }^{(4)}$ は希薄高分子水溶

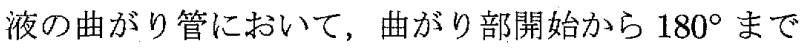
の流れ場の発達過程を, 断面の速度分布及び二次流れ の可視化観察から検討している.

一方, 非ニュートン流体の曲がり管流れの数值的研 究として，分子モデル(5), Power-law モデル ${ }^{(6) \sim(8)}, 2$ 次流体モデル ${ }^{(9)}$, UCM モデル ${ }^{(10)}$, Oldryod-B モデル (10) (11), 及び Oldryod3 定数モデル ${ }^{(10)}$ など様々なモ デルを用いた報告例がある。Tsang \& James ${ }^{(5)}$ は，高 分子水溶液のネットワーク構造による高い伸長粘度特 性が二次流れを減衰させるとした。また, Fan ら は，せん断粘度一定の粘弾性流体の完全発達円管内流

* 原稿受付 2009 年 2 月 3 日.

*I 正員, 名古屋工業大学大学院工学研究科 (严 466-8555 名古 屋市昭和区御器所町)

*2（株）小松製作所( $107-8414$ 東京都港区赤坂 2-3-6).

E-mail : tamano.shinji@nitech.ac.jp
れの数值シミュレーションにより，第一法線応力差は ニュートン流体と同じ向きの二次流れを強める方向に, 第二法線応力差は弱める方向にそれぞれ作用し, それ らのバランスにより二次流れが強くなるか弱くなるか が決定されるとしたここように，二次流れに及ぼす レオロジー特性が議論されてきているものの, ニュー トン流体のものと比較すると, 非ニュートン流体の曲 がり管流れの二次流れの発生メカニズムについては不 明な点が多い。

近年, 化学工学分野において, 多段屈曲構造を有す るマイクロチャネルの静的ミキサーとしての利用が注 目されてきている(12). Liu $5^{(13)}$ は，3 次元多段屈曲 構造を有するマイクロチャネルにおいて, Yamaguchi $ら^{(14)}$ は，多段へアピンカーブ構造を有するマイクロ チャネルにおいて, ニュートン流体の 2 液間の界面面 積が増加することにより，層流域における流体混合が 促進されることを報告している，一方，非ニュートン 流体については, Groisman \& Steinberg ${ }^{(15)(16)}$ 及び Burghelea $5^{(17)(18)}$ が, 分子量が大きい希薄高分子水 溶液の多段屈曲流路内流れにおいて, 溶液の弾性効果 によって誘起される弾性乱れ (Elastic turbulence) に より, 非常に低いレイノルズ数においても, 流体混合 が促進されることを明らかにしている。また, Pathak ら ${ }^{(19)}$ は，ジグザグマイクロチャネルに沶いて，第一 法線応力差と曲がり流線の複雑な複合効果により生じ る流れの不安定性 (弾性不安定性)により, 流体混合が 


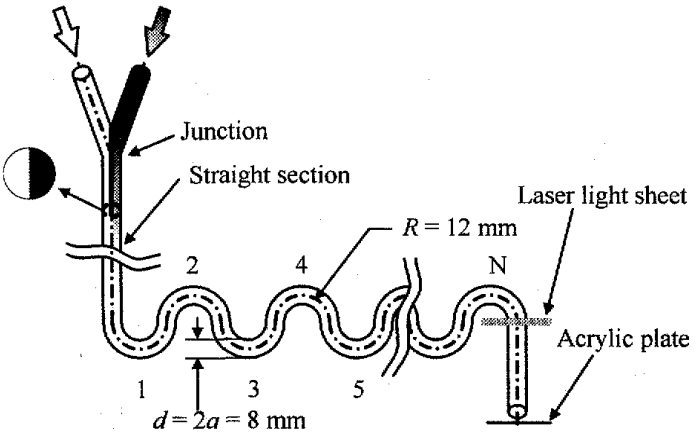

Fig. 1 Curvilinear pipe.

促進されるとしている，しかしながら，多段屈曲流路 における二次流れと流体混合効果との関連については 不明である。

本研究では，円形断面を有する単段及び多段屈曲流 路の下流直後の直管部において, 高分子水溶液の混合 の様子を可視化観察により明らかにすることを目的と する.さらに, 可視化画像の輝度值の標準偏差を算出 することにより，多段屈曲流路による流体混合促進効 果についても明らかにする.

\section{2. 実験装置及び方法}

図 1 に多段屈曲流路の概略図を示す. 流路は, 半 径 $a=4 \mathrm{~mm}$ の円形断面を有し, 流路中心線 半径 $R=12 \mathrm{~mm}$, 角度 $180^{\circ}$ の半円形のカーブを互 い違いに組名合わせたものである. 円形断面の半径 $a$ と流路中心線の曲率半径 $R$ の比である曲率半径比は $a / R=0.33$ である. 屈曲段数 $N$ は装置を組み替える ことにより，1から 60 まで様々に変化させることが出 来る. 本研究では， $N$ を $1,6 ， 32$ 及び 60 とした。 な お，円形断面を持つ流路は，厚さ $10 \mathrm{~mm}$ の透明アク リル板 2 枚それぞれに半円形の㴗を加工し, それらを 上下対称になるように重㸚ることにより製作した。

図 2 に実験装置の概略図を示す，実験装置は主とし て，2つのヘッドタンク，合流部，直管部及びテスト セクションから構成される．2つのヘッドタンクには 同じ作動流体が満たされるが，片側の流体には可視化 染料が混合される.2つのへッドタンクからそれぞれ 流出した流体は，ビニールチューブを通り合流部で 1 つの流路にまとめられる. 合流部直後では, 図 1 に示 すように直管部の垂直断面の左側に染料の混入してい ない流体, 右側に染料の混入した流体が左右対称に分 かれる. 流体はその後, 長さ $446 \mathrm{~mm}(\simeq 56 d)$ の直管 部を通って十分発達した後, テストセクションに流入 する.そして，テストセクションを通過した流体は流 路出口から長さ $46 \mathrm{~mm}$ の下流直管部を通って流出す

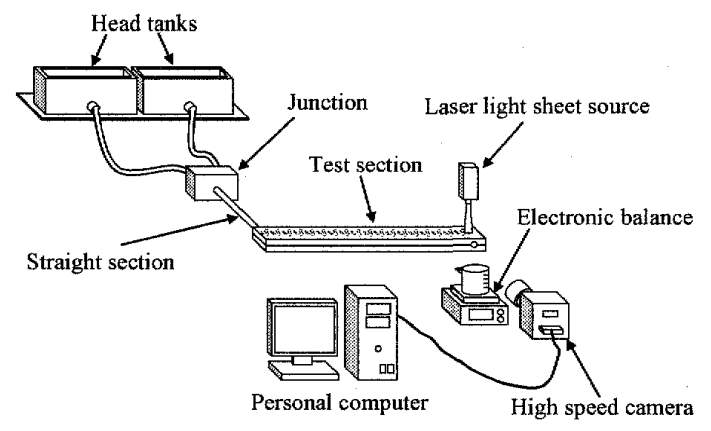

Fig. 2 Experimental setup.

る.流路出口には，下流方向からの可視化観察を行な うために，透明なアクリル板が僅かな隙間 ( $\leq 1 \mathrm{~mm})$ を空けて設置されている，重量法により流量 $Q$ を求 め, ヘッドタンクの高さを変えることにより $Q$ を調 節した。なお，実験の際，作動流体の流出によるへッ ド差の変化を $3 \%$ 以下とした.

流体混合の可視化観察実験では，可視化用染料として ローダミン B(Rhodamine B, ナカライテスク (株) 製) 学作動流体に 2 ppm 加えた: Nd: YAG レーザーシー 卜光源 $(1.5 \mathrm{~W}$, 厚さ約 $3 \mathrm{~mm}$, 波長 $532 \mathrm{~nm}$, DPSS Green Laser, (株) 日本レーザー製) により流路垂直 断面を光切断し，マイクロレンズ (Micro Nikkor 105 mm F2.8S，PN-11，(株) ニコン製)を取り付けた高速 度ビデオカメラ (FASTCAM-1024PCI，(株)Photoron 製)を用いて，流路出口に設置した透明アクリル板を 通して下流方向から撮影した。本研究において，下流 直管部において，最終曲がり管の終端を原点とし，主 流方向に $z^{\prime}$ 軸を取った. 可視化観察におうる撮影位置 は，レーザーシート光の厚さの中心が， $z^{\prime}=1.5 \mathrm{~mm}$ となる位置 (曲がり管下流直管部) とした。なお，本 研究では, 曲率半径比が $a / R=0.33$ であり, 従来の 横山・富田 ${ }^{(4)}$ の研究の $a / R=0.033$ よりもかなり大き く，曲がり管部における流路垂直断面での撮影画像に 屈折率の影響が強く現れたため，現時点においては， 曲がり管部での可視化観察は行なえていない.

作動流体として, ポリアクリルアミド (Polyacrylamide, SANFLOC AH70P, 分子量 $200 \sim 400$ 万, 三洋化成工業 (株) 製) を水道水に溶解させたものを使 用した．所定量のポリアクリルアミド $(\mathrm{PAA})$ を少量 ずつ混合し，機械的なせん断による劣化を防ぐため， 手で約 30 分攪挥することにより PAA 水溶液を作成し た. その後, 1 日以上放置し, PAA 水溶液中の気泡を 取り除いた。また。実験直前に，PAA 水溶液をるる い(目開き: $0.5 \mathrm{~mm}$ )にかけ，僅かではあるが溶けき らなかったPAA を除去し，再び手でよく攪拌して容 
Table 1 Rheological properties for PAA solutions.

\begin{tabular}{cccccc}
\hline \hline PAA (wt\%) & $\eta_{0}(\mathrm{~Pa} \mathrm{~s})$ & $\lambda(\mathrm{s})$ & $\alpha$ & $\beta$ & $E_{0}$ \\
\hline 0.05 & 0.20 & 1.8 & 0.15 & 0.035 & 5.6 \\
0.1 & 0.28 & 3.0 & 0.15 & 0.030 & 13 \\
\hline \hline
\end{tabular}

器内の濃度の分布が一様になるようにした.PAA 水 溶液の密度 $\rho$ は, 水と等しいものとした. 本研究では, $\mathrm{PAA}$ 水溶液の濃度は，0.05 及び $0.1 \mathrm{wt} \%$ の 2 種類と

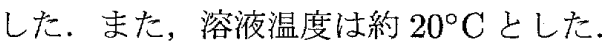

使用したPAA 0.05 及び 0.1 wt\%のゼロせん断粘 度 $\eta_{0}$ ，緩和時間 $\lambda$, Giesekus モデルのモビリティー 係数 $\alpha$ ，ゼロせん断粘度に対する溶媒のせ九断粘度 $\beta$ ， 及び弾性数 $E_{0}=\lambda \eta_{0} /\left(4 \rho a^{2}\right)$ を表 1 に示す. ここで, $\eta_{0}, \lambda ， \alpha$ 及び $\beta$ は，せん断粘度と第一法線応力差の 測定結果 (図は示されていない) が単純せん断流れに おけるGiesekus モデルの近似曲線に最も合うように

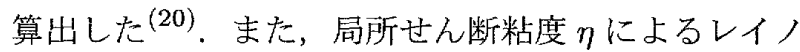
ルズ数 $R e$ は次式により定義される。

$$
R e=\frac{2 \rho a V_{m}}{\eta}
$$

ここで， $V_{m}$ は断面平均速度である。また， 面せん断速度 $\dot{\gamma}_{w}$ における壁面せん断粘度の值を用い た。 $\dot{\gamma}_{w}$ は，Giesekus モデルでは算出が困難であるた め，流れを定常層流のべき乗則流体のポアズイユ流れ と仮定することにより得られる次式により求めた ${ }^{(21)}$.

$$
\dot{\gamma}_{w}=\frac{3 n+1}{n} \frac{Q}{\pi a^{3}}
$$

ここで， $n$ はべき乗則モデルの指数であり，せん断速 度に対するせん断粘度の測定值を両対数グラフで直 線近似することにより，PAA 0.05 及び $0.1 \mathrm{wt} \%$ 共に $n=0.38$ を得た。

\section{3. 可視化観察結果}

本節では，屈曲段数 $N=1 ， 6 ， 32$ 及び 60 につい て, Glycerin $50 \%$ 水溶液, PAA 0.05 及び $0.1 \mathrm{wt} \%$ 水溶液の流路垂直断面での可視化観察結果を示寸，本 節で示す可視化画像において，円形断面の左側は流路 の曲がりの内側，右側は曲がり外側に対灾する.また， 図の左から右の順にレイノルズ数 Re が大きくなる. 白く写っているのが染料であり，白色が強いほど染料 の濃度が高いことを意味する．染料を含里作動流体は 初期に， $N=1$ では，曲がり管部の内側に， $N=6$, 32,60 では，最終曲がり管部の外側に入っている.

$3 \cdot 1$ 屈曲段数 $N=1$ 図 3 に, $N=1$ におけ る可視化観察結果を示す。図 3(a) より，Glycerin 50 $\%$ 水溶液の場合，Reが大きくなるのに伴い，染料が 断面中央部分で曲がりの外側に張り出し, さらに壁に
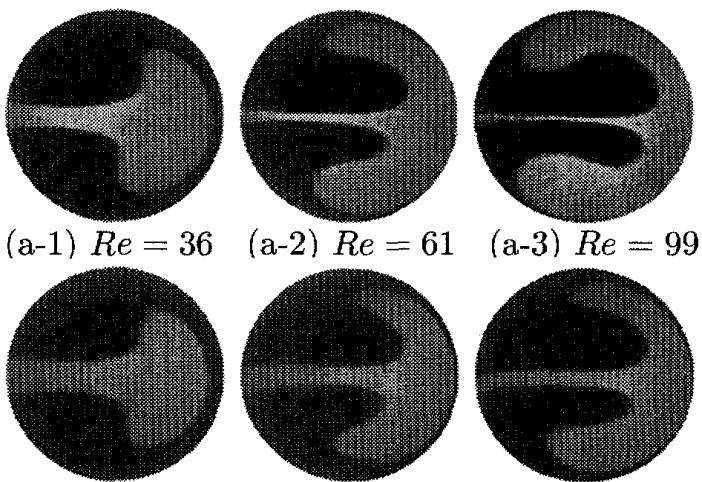

(b-1) $R e=31$
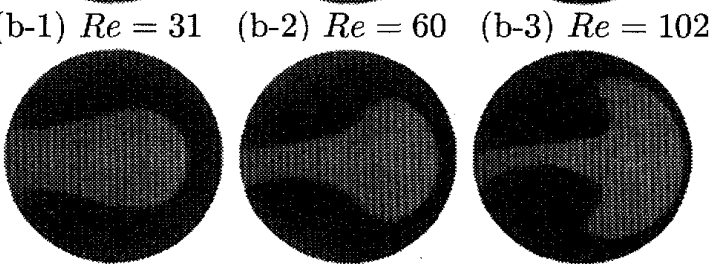

(c-1) $R e=31$

(c-2) $R e=60$

(c-3) $R e=94$

Fig. 3 Flow visualization at $N=1$ : (a) Glycerin $50 \%$, (b) PAA 0.05 wt $\%$, and (c) PAA 0.1 wt $\%$.

沿って曲がりの内側方向に流れる様子が見て取れる. これは，断面中央で外向きに流れる二次流れが $R e$ の 増加に伴い強くなるためである. PAA 0.05，0.1 wt\% 水溶液の場合，染料の分布パターンが Glycerin $50 \%$ 水溶液のもの上同様であり [図 3(b), (c)], 断面中央部 で曲がり外向きの二次流れであると推察される。この ことは，層流の場合，水と PEO $100 \mathrm{ppm}$ 水溶液の二 次流れの渦の発達パターンに明瞭な違いがないとした 横山・富田 ${ }^{(4)} の$ 知見と整合している。 また, Glycerin $50 \%$ 水溶液, PAA 0.05, $0.1 \mathrm{wt} \%$ 水溶液の順に, 染 料の広がり幅が小さくなる。これは，PAA 水溶液の 濃度が高くなるにつれて，二次流れの強さが弱くなる ことを示唆している.このことは, Tsang \& James ${ }^{(5)}$ の知見とも整合している. なおう, $N=1$ の場合，案験 を行った $R e$ の範囲 $(R e<150)$ では， 2 液が混合して いる様子は見られなかった。

$3 \cdot 2$ 屈曲段数 $N=6$ 図 4 に, $N=6$ におけ る可視化観察結果を示す. Glycerin $50 \%$ 水溶液にお いて， $R e=38$ では，流路入口で鉛直であった 2 液間 の境界面が，奇数段と偶数段とで交互に外向きの遠心 力を受けるため，大きく湾曲した形状になる [図 4(a1)]. $R e$ が増加すると, 2 液間の境界面はさらに湾曲 寸る [図 4(a-2)].Re=94 では，壁面に沿って曲がり の内向きに伸びていた染料がほとんどなくなり，染料 の入った流体は断面の中央付近に集まることが分かる [図 4(a-3)].

PAA $0.05 \mathrm{wt} \%$ 水溶液について, 図 4(b-1)より, 


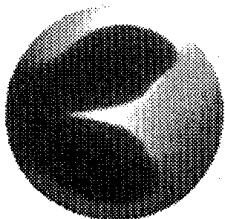

(a-1) $R e=38$

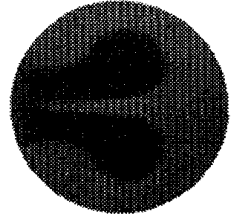

(b-1) $R e=32$

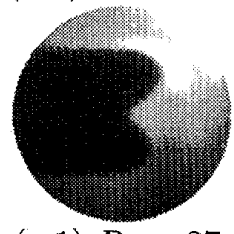

(c-1) $R e=27$

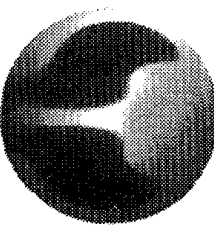

(a-2) $R e=50$

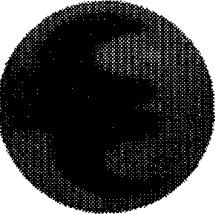

(b-2) $R e=64$

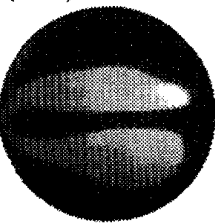

(c-2) $R e=65$

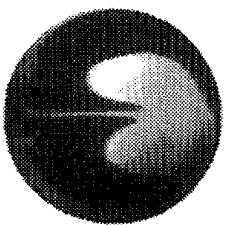

(a-3) $R e=94$

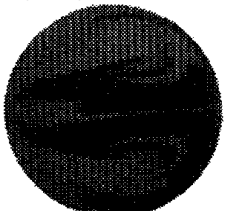

(b-3) $R e=99$

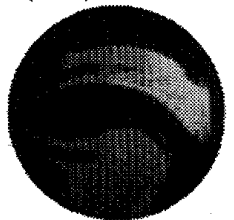

(c-3) $R e=98$
Fig. 4 Flow visualization at $N=6$ : (a) Glycerin $50 \%$, (b) PAA $0.05 \mathrm{wt} \%$, and (c) PAA 0.1 wt $\%$.

$R e=32$ では, Glycerin $50 \%$ 水溶液の場合 [図 4(a1)] と染料の分布が似ていることが分かる. $R e=64$ では，2 液間の境界面が湾曲し，Glycerin $50 \%$ 水溶 液の場合よりも複雑な形状となる [図 4(b-2)]. また, $R e=64$ では, $R e=32$ の場合よりも染料部分が中央 部付近で外側に窪んでいるため, 中央部付近では外向 きの二次流れとなっていると推測される. $R e=99$ で は，染料の入っている部分が中央部で曲がりの内側に 向かって伸びており [図 4(b-3)], 中央部で内向き流れ となっていると考えられる.つまり，Re=64と99 の間で二次流れの向きが逆転したと推察される。

PAA $0.1 \mathrm{wt} \%$ 水溶液について, 図 $4(\mathrm{c}-1)$ より, $R e=$ 27 では，二次流れパターンは Glycerin $50 \%$ 水溶液及 び PAA $0.05 \mathrm{wt} \%$ 水溶液のものに似ているが，染料 の界面の変形度合いは小さく, 二次流れは弱くなるこ とが分かる. $R e=65$ では，中央部において曲がりの 内向きに向かう二次流れパターンが見られる [図 4(c2)]. $R e=98$ では, 上下の非対称性が見られるもの の, $R e=65$ の場合亡同様の二次流れパターンが観察 される [図 4(c-3)].

屈曲段数 $N=6$ の場合, 同程度の $\operatorname{Re} \omega N=1$ の場 合と比較して，溶液に依らず境界面の変形の度合いが 大きくなるが，2液の混合が進んでいる様子は， $N=1$ の場合と同様に見られない。

$3 \cdot 3$ 屈曲段数 $N=32$ 図 5 に, $N=32$ におけ る可視化観察結果を示す。図 5(a) より，Glycerin 50 $\%$ 水溶液では, $N=6$ の場合 [図 4(a)] と比較して, 曲

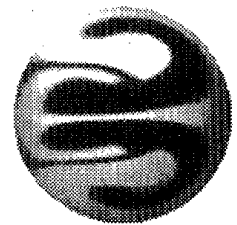

(a-1) $R e=30$

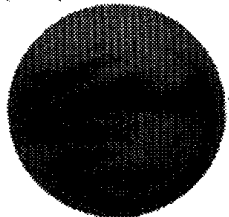

(b-1) $R e=30$

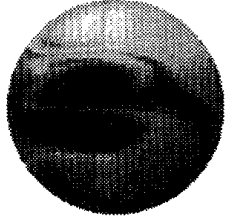

(c-1) $R e=35$

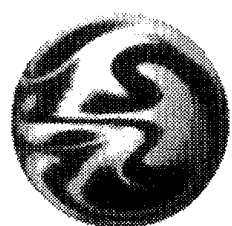

(a-2) $R e=54$

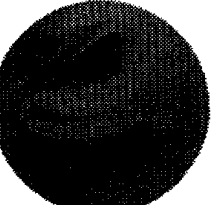

(b-2) $R e=61$

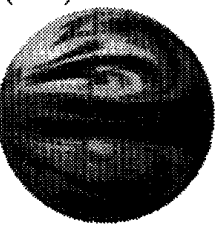

(c-2) $R e=60$

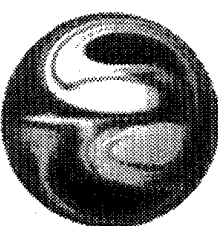

(a-3) $R e=106$

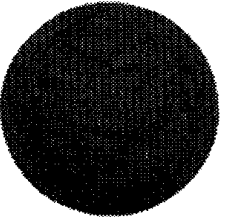

(b-3) $R e=85$

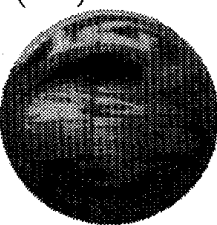

(c-3) $R e=73$
Fig. 5 Flow visualization at $N=32$ : (a) Glycerin $50 \%$, (b) PAA $0.05 \mathrm{wt} \%$, and (c) PAA 0.1 wt\%.

がり段数が増加しているために，2 液間の境界面はか なり複雑になることが分かる。また，図 $5(\mathrm{a}-3) よ り ，$ $R e=106$ では，N=6の場合 [図 4(a-3)]よりも，染 料が断面に広く分布していることが分かる。ただし， 染料の濃度の濃い領域は中央部付近にあり：この点は $N=6$ の場合と同じである.

PAA 0.05 wt\% 水溶液について, 図 5(b-1)より, $R e=30$ では, $N=6$ の場合 [図 4(b-1)] よりも, 2 液間の界面が不明確で, 複雑であることが分かる. $R e=61$ では，二次流れが断面中央で内向きであるこ と [図 5(b-2)], $R e=85$ では, 染料が断面全体に分布 しており，2 液間の混合がかなり進んでいること[図 5(b-3)] が分かる.

PAA 0.1 wt\% の場合 [図 5(c)] の二次流れパターン の変化の様子は, PAA $0.05 \mathrm{wt} \%$ の場合 [図 5(b)] と 類似している.

$3 \cdot 4$ 屈曲段数 $N=60$ 図 6 に， $N=60$ にお ける可視化観察結果を示す，Glycerin $50 \%$ 水溶液の 場合, 図 6(a)より，Reによる二次流れと混合の変化 の様子は，N=32の場合 [図 $5(\mathrm{a})]$ とほとんど変わら ないことが分かる.しかし，Reがほぼ同じ場合には， $N=32$ の場合よりも 2 液界面が不明確であり，混合 が促進されているように見える.

PAA 0.05 wt\% 水溶液について. 図 6(b-1)より, $R e=30$ では, 流れのパターンは $N=32$ の場合 [図 5(b-1)] と類似しているが，混合はより促進されて いることが分かる. 図 5(b-2), 5(b-3) の静止画像から 
2126
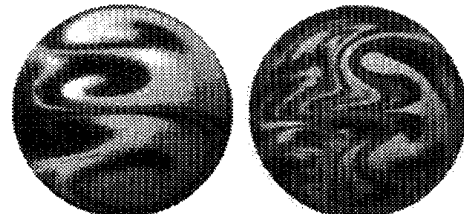

(a-2) $R e=60$

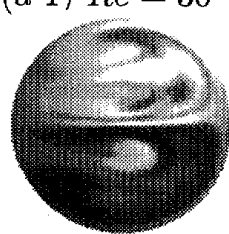

(b-1) $R e=30$

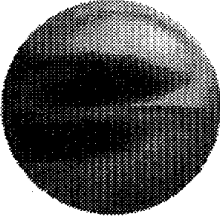

(c-1) $R e=30$

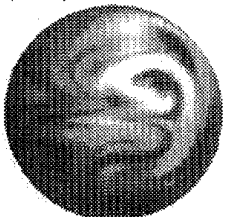

(b-2) $R e=59$

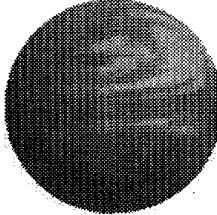

(c-2) $R e=60$

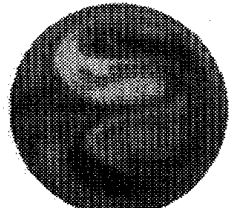

(a-3) $R e=103$

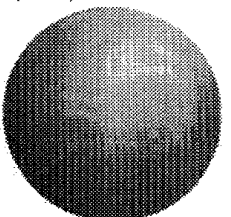

(b-3) $R e=110$

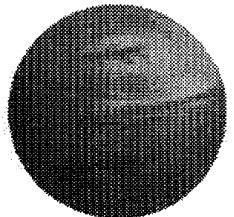

(c-3) $R e=91$

Fig. 6 Flow visualization at $N=60$ : (a) Glycerin $50 \%$, (b) PAA $0.05 \mathrm{wt} \%$, and (c) PAA 0.1 wt $\%$.

では分かりにくいが， $R e=59$ では中央で外向き流 れ, $R e=110$ では中央で内向き流れとなっており, $R e=59$ と 110 の間において, 二次流れの向きが逆転 する。また， $R e=110$ では，染料の分布がほぼ均一と なっており，流体混合が十分に進んでいることが推察 される、なお，この時の $\operatorname{Re}(=110)$ は，Glycerin 50 \% 水溶液において染料分布がほぼ均一となる $R e$ の約 半分である(図は示されていない).

PAA $0.1 \mathrm{wt} \%$ 水溶液について, 図6(c-1) より, Re= 30 では，二次流れの様子は，PAA $0.05 \mathrm{wt} \%$ 水溶液 の場合 [図 6(b-1)] と変らず，中央で内向き流れである ことが分かる. $R e=60$ では，静止画からは分かり にくいが，中央付近で二次流れの向きは内占きである [図 6(c-2)]. つまり, Re=30と60の間で二次流れパ ターンが変化したと推察される.また， $R e=91$ まで レイノルズ数が増加しても， $R e=60$ での二次流れパ ターンから変化した様子は見られない[図 6(c-3)].

なお，可視化観察により得られた動画から，Glycerin $50 \%$ 水溶液の場合には，界面の摇動は全く観察され なかったのに対して，PAA 水溶液の場合には，非常 に僅かではあるが非周期的な界面の摇動が観察され た.この界面の摇動は，高分子水溶液の持つ弾性の影 響であると考えられるが，弾性乱れ ${ }^{(15)}$ 及び弾性不安 定性 ${ }^{(19)}$ との関連については，現時点では不明である。 また, Arratia $ら^{(22)}$ は，高分子水溶液のせ九断粘度の shear-thinning 特性には流体混合を促進する効果があ ると報告しているが，本研究では， shear-thinning 特

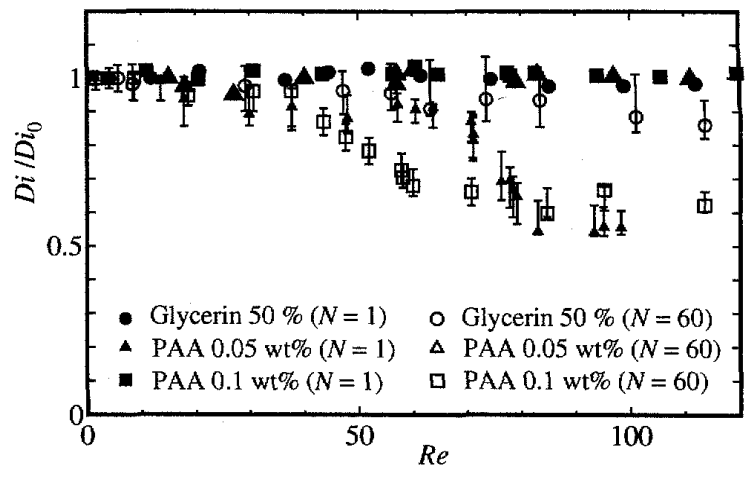

Fig. 7 Standard deviation of brightness.

性と粘弾性効果とを併せ持つPAA 水溶液を用いてい るため, shear-thinning 特性のみの混合促進効果につ いては不明である、今後, 流体混合促進のメカニズム のさらなる理解のためには，曲がり管部にお゙ける二次 流れ挙動, 曲がり管の断面形状及び曲率半径比の二次 流れに及ぼす影響などについても，解明が求められる。

3.5 混合度の評価取得した画像の輝度值分布 より，次式で定義される輝度值の標準偏差 $D i$ を算出 し， 2 液の混合度合いを評価する ${ }^{(13)}$.

$$
D i=\sqrt{\frac{1}{n} \sum_{i=1}^{n}\left(I_{i}-I_{\max }\right)^{2}}
$$

ここで， $n$ はピクセル数， $I_{i}$ はピクセル $i$ 輝度值, $I_{\text {max }}$ は解析画像内における最大の輝度值である.

図 7 に $N=1,60$ における Glycerin $50 \%$ 水溶 液, PAA 0.05 及び $0.1 \mathrm{wt} \%$ 水溶液の輝度值の標準偏 差 $D i / D i_{0}$ の Re に対する変化を示す.ここで, $D i_{0}$ は，実験を行った最も低いReにおける輝度值の標準 偏差である， $N=1$ では，溶液に依らず， $R e$ が増加 しても混合はほとんど進行しない，一方，N=60で は, Glycerin $50 \%$ 水溶液の場合には，Reの増加に 伴い $D i / D i_{0}$ が緩やかに減少しており，徐々に混合が 進むのに対して, PAA $0.05 \mathrm{wt} \%$ 水溶液の場合には, $R e \simeq 60$ において, $D i / D i_{0}$ の減少割合が急に大きく なり，混合が急激に促進されることが分かる．また， $R e>80$ においては， $D i / D i_{0}$ はほぼ一定值 $(\simeq 0.6)$ となり，実験を行った定常流れと見なせる $R e$ の範囲 $(R e \leq 100)$ では，完全に均一な混合 $\left(D i / D i_{0}=0\right)$ と はならなかった. PAA $0.1 \mathrm{wt} \%$ 水溶液では，Re $\simeq 40$ において, PAA 0.05 wt\%の場合と同様に，急激に混 合が促進されるが，その值 (=40) はPAA 0.05 wt\% 水溶液の值 $(=60)$ に比べて小さい。これらの混合が 急激に促進され始めるRe は，可視化観察によって確 認された二次流れパターンが変化する $R e$ とほぼ詨応 している. 
ここで，混合度合いは，作動流体がテストセクショ ン内に留まっている時間 (滞留時間) が長くなる程, 分 子拡散の影響を強く受けると考えられる，本研究では， レイノルズ数が大きくなる程, 平均流速が大きくなり, 滞留時間は短くなる.このことから，本研究で観察さ れたレイノルズ数の増加に伴う流体混合促進効果は, 帯留時間が増加したことに起因するものではないと言 える.

\section{4. 結言}

本研究では, Glycerin 50\% 水溶液, 粘弾性流体で ある高分子水溶液 (PAA 0.05 及び $0.1 \mathrm{wt} \%$ 水溶液) について，円形断面を有寸る多段屈曲流路 (屈曲段数 $N=1 ， 6 ， 32$ 及び 60) の下流直後の直管部において， 流体混合の可視化観察を行い，以下の結論を得た。

(1) $N=6$ の場合, 同程度のレイノルズ数 $R e$ の $N=1$ の場合と比較して，溶液濃度に依らず境界面 の変形の度合いが大さくなるが，2液の混合が進んで いる様子は， $N=1$ の場合と同様に見られない。 た， $N=1,6$ の場合は共に, PAA $0.1 \mathrm{wt} \%$ 水溶液の 方が，PAA $0.05 \mathrm{wt} \%$ 水溶液よりも染料の広がり幅が 小さく，二次流れが弱くなる.

(2) $N=32$ の場合， $N=6$ の場合に比べて，2 液 間の界面がさらに複雑になり，Re の増加に伴い，染 料が断面全体に分布するようになる。なお，この傾向 はPAA 0.1 及び $0.05 \mathrm{wt} \%$ 水溶液とで同じである.

(3) $N=60$ の場合, PAA $0.1 \mathrm{wt} \%$ 水溶液では $R e \simeq$ 40 において, PAA $0.05 \mathrm{wt} \%$ 水溶液では $R e \simeq 60$ に おいて，それぞれ流体混合が急激に促進される。また， 流体混合が急激に促進され始めるRe は，可視化観察 によって確認された二次流れパターンが変化する $R e$ とほぼ対忘する。

\section{謝 辞}

本研究に精力的に協力された馬場貴之氏 (当時，名 古屋工業大学機械工学科卒研生) に感謝する. 本研究 は，平成 19,20 年度科学研究費補助金若手研究 $(B)$ (課 題番号 No. 19760113) の補助を受けている.ここに記 して感謝の意を表す。

\section{文献}

(1) Berger S. A., Talbot L., and Yao L.-S., Flow in curved pipes, Ann. Rev. Fluid Mech., 15, (1983), 461-512.

(2) Itō H., Flow in curved pipes, JSME Int. J., 30, (1987), 543-552.

(3) Jones W. M. and Davies O. H., The flow of dilute aqueous solutions of macromolecules in various geometries: III. Bent pipes and porous materials, J. Phys. D: Appl. Phys., 9, (1976), 753-770.
(4) Yokoyama T. and Tomita Y., Flow on dilute polymer solutions through curved pipes (Flow in inlet region), Trans. JSME, Ser. B, 56, (1990), 983-989.

(5) Tsang H. Y. and James D. F., Reduction of secondary motion in curved tubes by polymer additives, J. Rheol., 24, (1980), 589-601.

(6) Hsu C.-F. and Patankar S. V., Analysis of laminar nonNewtonian flow and heat transfer in curved tubes, AIChE $J .$, 28, (1982), 610-617.

(7) Iemoto Y., Nagata M., and Yamamoto F., Steady laminar flow of a power-law fluid in a curved pipe of circular cross-section with varying curvature, J. NonNewtonian Fluid Mech., 19, (1985), 161-183.

(8) Takami T., Sudou K., and Tomita Y., Flow on nonNewtonian fluids in curved pipes (1st report, numerical analysis for laminar flow of power-law fluids), Trans. JSME, Ser. B, 84, (1986), 1228-1234.

(9) Jitchote W. and Robertson A. M., Flow of second order fluids in curved pipes, J. Non-Newtonian Fluid Mech., 90, (2000), 91-116.

(10) Fan Y., Tanner R. I., and Phan-Thien N., Fully developed viscous and viscoelastic flows in curved pipes, J. Fluid Mech., 440, (2001), 327-357.

(11) Zhang M. K., Shen X. R., Ma J. F., and Zhang B. Z., Galerkin method study on flow of Oldroyd-B fluids in curved circular cross-section pipes, J. Zhejiang Univ. SCIENCE A, 7, (2006), 263-270.

(12) Hessel V., Löwe H., and Schönfeld F., Micromixers-a review on passive and active mixing principles, Chem. Eng. Sci., 60, (2005), 2479-2501.

(13) Liu R. H., Stremler M. A., Sharp K. V., Olsen M. G., Santiago J. G., Adrian R. J., Aref H., and Beebe D. J., Passive mixing in a three-dimensional serpentine microchannel, J. Microelectromech. Syst., 9, (2000), 190197.

(14) Yamaguchi Y., Takagi F., Yamashita K., Nakamura H., Maeda H., Sotowa K., Kusakabe K., Yamasaki Y., and Morooka S., 3-D simulation and visualization of laminar flow in a microchannel with hair-pin curves, AIChE J., 50, (2004), 1530-1535.

(15) Groisman A. and Steinberg V., Efficient mixing at low Reynolds numbers using polymer additives, Nature, 410, (2001), 905-907.

(16) Groisman A. and Steinberg V., Elastic turbulence in curvilinear flows of polymer solutions, New J. Phys., 6 , No. 29, (2004).

(17) Burghelea T., Segre E., and Steinberg V., Mixing by polymers: Experimental test of decay regime of mixing, Phys. Rev. Lett., 92, No. 164501, (2004).

(18) Burghelea T., Segre E., Bar-Joseph I., Groisman A., and Steinberg V., Chaotic flow and efficient mixing in a microchannel with a polymer solution, Phys. Rev. E, 69, No. 066305, (2004).

(19) Pathak J. A., Ross D., Migler K. B., Elastic flow instability, curved streamlines, and mixing in microfluidic flows, Phys. Fluids, 16, (2004), 4028-4034.

(20) Tamano S., Itoh M., Ide Y., and Yokota K., Vortex shedding in confined swirling flow of polymer solutions, Phys. Fluids, 19, No. 023103, (2007).

(21) Bird R. B., Armstrong R. C., and Hassager O., Dynamics of Polymeric Liquids. Volume 1: Fluid Mechanics, 2nd ed. (1987), Wiley Interscience.

(22) Arratia P. E., Voth G. A., Gollub J. P., Stretching and mixing of non-Newtonian fluids in time-periodic flows, Phys. Fluids, 17, No. 053102, (2005). 